\title{
PELATIHAN PEMBUATAN PESTISIDAN NABATI
}

\author{
Ikhsan $^{1}$, Lutfi Samaduri \\ Fakultas Pertanian Universitas Muhammadiyah Luwuk \\ lutpisamaduri@gmail.com
}

\begin{abstract}
ABSTRAK
Desa Tambale merupakan salah satu desa di Kecamatan Mamosalato yang mayoritas masyarakatnya bermata pencaharian sebagai petani. Selama ini dalam melakukan budidaya tanaman perkebunan, petani di Desa ini selalu menggunakan pestisida kimia yang didapatkan di toko pertanian. Tentunya hal ini menambah beban biaya bagi para petani. Padahal disisi lain banyak potensi sumberdaya desa yang dapat diolah dan dijadikan sebagai pestisida nabati. Namun beberapa kendala yang dihadapi para petani salah satunya adalah kemampuan petani dalam membuat pestisida nabati yang masih sangat rendah bahkan selama ini mereka belum mampu untuk membuat pestisida nabati ini. Kegiatan pelatihan pembuatan pestisida nabati bertujuan Untuk meningkatakan keterampilan petani dalam membuat pestisida nabati sebagai alternatif pestisida dalam menjalankan usahatani dan Petani mampu membuat pestisida nabati.

Kegiatan ini dilaksanakan pada tanggal 16 - 19 Februari 2018, bertempat didesa Tambale tepatnya di Balai Desa Tambale Kecamatan mamosalato. Hasilnya Tingkat pasrtisipasi masyarakat cukup baik, sehingga kegiatan yang dijalankan dapat memberikan dampak posistif bagi petani serta Meningkatnya keterampilan masyarakat dalam membuat pestisida nabati sehingga kedepannya mereka mampu membuat sendiri pestisida untuk kebutuhan usahatani mereka.
\end{abstract}

Kata Kunci : Pestisida Nabati, Pelatihan, Petani

\section{PENDAHULUAN}

Pestisida nabati adalah pestisida yang bahan dasarnya berasal dari tumbuhan. Pestisida nabati sudah dipraktikkan 3 abad yang lalu. Pada tahun 1690, petani di Perancis telah menggunakan perasan daun tembakau untuk mengendalikan hama kepik pada tanaman buah persik. Tahun 1800, bubuk tanaman Pyrethrum digunakan untuk mengendalikan kutu. Penggunaan pestisida nabati selain dapat mengurangi pencemaran lingkungan, harganya relatif lebih murah apabila dibandingkan dengan pestisida kimia (Subiyakto Sudarmo, 2005).

Menurut Agus Kardinan (2002), karena terbuat dari bahan alami/nabati maka jenis pestisida ini bersifat mudah terurai di alam jadi residunya singkat sekali. Pestisida nabati besifat "pukul dan lari" yaitu apabila diaplikasikan akan membunuh hama pada waktu itu dan setelah terbunuh maka residunya cepat menghilang di alam. Jadi tanaman akan terbebas dari residu sehingga tanaman aman untuk dikonsumsi. Subiyakto Sudarmo (2005) menyatakan bahwa pestisida nabati dapat membunuh atau mengganggu serangga hama dan penyakit melalui cara kerja yang unik yaitu dapat melalui perpaduan berbagai cara atau secara tunggal. Cara kerja pestisida nabati sangat spesifik (Subiyakto Sudarmo, 2005) yaitu:

a. Merusak perkembangan telur, larva, dan pupa

b. Menghambat pergantian kulit

c. Mengganggu komunikasi serangga

d. Menyebabkan serangga menolak makan

e. Menghambat reproduksi serangga betina

f. Mengurangi nafsu makan

g. Memblokir kemampuan makan serangga 
h. Mengusir serangga (repellent)

i. Menghambat perkembangan patogen penyakit

Tumbuhan pada dasarnya mengandung banyak bahan kimia yang merupakan produksi metabolit sekunder dan digunakan oleh tumbuhan sebagai alat pertahanan dari serangan OPT. Lebih dari 2.400 jenis tumbuhan yang termasuk ke dalam 235 famili dilaporkan mengandung bahan pestisida. Oleh karena itu, jika dapat mengolah tumbuhan ini sebagai bahan pestisida maka akan membantu masyarakat petani untuk menggunakan pengendalian yang ramah lingkungan dengan memanfaatkan sumber daya setempat yang ada di sekitarnya (Agus Kardinan, 2002)

Pemanfaatan pestisida nabati mempunyai beberapa kelebihan, Haryono (2011) menjelaskan kelebihan pestisida nabati, yaitu:

a. Pestisida nabati relatif lebih mudah dibuat

b. Lebih mudah terurai di alam

c. Lebih aman bagi manusia dan lingkungan

d. Pemanfaatan pestisida nabati dalam pengendalian OPT, selain sebagai pengendali alamiah yang efektif dan berkelanjutan, juga dapat berperan dalam meningkatkan daya saing produk melalui peningkatan efisiensi usaha dan image produk perkebunan ramah lingkungan.

e. Pemanfaatan pestisida nabati secara luas akan langsung berpengaruh terhadap berkurangnya volume penggunaan pestisida dan berdampak positif terhadap kualitas produk tanaman terutama dengan semakin terhindarnya produk dari kemungkinan pencemaran residu pestisida kimiawi.

Desa Tambale merupakan salah satu desa di Kecamatan Mamosalato yang mayoritas masyarakatnya bermata pencaharian sebagai petani. Selama ini dalam melakukan budidaya tanaman perkebunan, petani di Desa ini selalu menggunakan pestisida kimia yang didapatkan di toko pertanian. Tentunya hal ini menambah beban biaya bagi para petani. Padahal disisi lain banyak potensi sumberdaya desa yang dapat diolah dan dijadikan sebagai pestisida nabati. Namun beberapa kendala yang dihadapi para petani salah satunya adalah kemampuan petani dalam membuat pestisida nabati yang masih sangat rendah bahkan selama ini mereka belum mampu untuk membuat pestisida nabati ini.

Berdasarkan hal tersebut, saya sebagai mahasiswa KKN angkatan ke XXIV mengakat artikel ilmiah dengan judul Pelatihan Pembuatan Pestisidan Nabati. Hal ini dilakukan untuk memberikan alternatif pestisida bagi petani dalam menjalankan usahatani mereka

\section{TUJUAN}

Kegiatan pelatihan pembuatan pestisida nabati bertujuan :

1. Untuk meningkatakan keterampilan petani dalam membuat pestisida nabati sebagai alternatif pestisida dalam menjalankan usahatani.

2. Petani mampu membuat pestisida nabati

\section{METODE}

\section{Waktu dan Tempat Pelaksanaan Kegiatan}

Kegiatan ini dilaksanakan pada tanggal 16 - 19 Februari 2018, bertempat didesa Tambale tepatnya di Balai Desa Tambale Kecamatan mamosalato.

\section{Persiapan alat dan bahan}

Penyampaian kepada masyarakat agar bisa dapat mengumpulkan alat dan bahan yang akan di butuhkan dalam pembuatan pestisida nabati di antaranya :

$$
\begin{array}{ll}
\text { 1. Alat } \\
\text { - } & \text { Parang, } \\
\text { - } & \text { Pisau } \\
\text { - } & \text { Jergen } \\
\text { - } & \text { Ember } \\
\text { - } & \text { Saringan }
\end{array}
$$


2. Bahan

- Air

- Daun Srikaya

- Sabun

\section{Prosedur Kerja}

Langkah-langkah dalam pelaksanaan pelatihan pembuatan Pestisida Nabati dan kegunaan alat-alat yang di pakai yaitu

\begin{tabular}{|c|c|c|c|}
\hline $\begin{array}{c}\text { Tahapan } \\
\text { Pelaksanaan }\end{array}$ & Kegiatan & Metode & Materi \\
\hline \multirow[t]{2}{*}{ Pelaksanaan } & $\begin{array}{l}\text { Sosialisasi ke } \\
\text { Masyarakat } \\
\text { sasaran }\end{array}$ & $\begin{array}{l}\text { Pertemuan dengan } \\
\text { masyarakat } \\
\text { Sasaran }\end{array}$ & 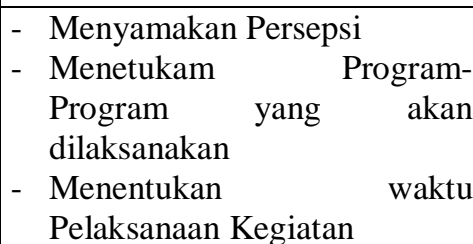 \\
\hline & Palaksanaan & Partisipatif & 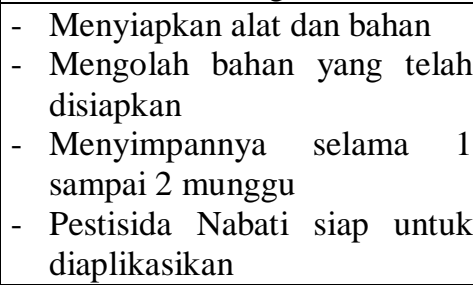 \\
\hline
\end{tabular}

\section{HASIL DAN PEMBAHASAN}

Pelaksanaan kegiatan "Pelatihan Pembuatan Pestisida Nabati Di Desa Tambale Kecamatan Mamosalato" dilakukan pada bulan februari 2018. Pada tahap awal pelaksanaan program dilaksanakan kegiatan berupa persiapan awal yakni penyamaan persepsi, penentuan jadwal pelaksanaan kegiatan, persiapan alat dan bahan yang yang dibutuhkan terutama bahan baku daun srikaya. Penentuan masyarakat sasaran yang akan dihadirkan sampai dengan sosialisasi dan pelaksanaan kegiatan. Pelaksanaan kegiatan didasarkan pada analisis situasi yang didapatkan pada saat obeservasi dan hasil pengamatan dimana sangat banyak daun srikaya yang hanya dibiarkan rusak begitu saja tanpa melalu pengolahan. Dari hasil wawancara dan observasi itulah kegiatan ini dianggap penting untuk dilakukan sebagai salah satu alternatif pemanfaatan sumberdaya alam yang dianggap tidak bermanfaat lagi menjadi produk yang bernilai ekonomi dan berguna bagi petani pada khususnya.

Dalam rangka penyamaan persepsi dan waktu pelaksanaan kegiatan, maka pertama-tama dilaksanakan kegiatan sosialisasi dan koordinasi dengan masyarakat sasaran dalam hal ini petani untuk menyamakan persepsi waktu dan kegiatan yang akan dilaksanakan. Hal ini dilakukan untuk mendapatkan kesepakatan waktu dan jadwal dalam pelaksanaan program dan perlu disyukuri bahwa partisipasi masyarakat dalam pelaksanaan program cukup baik sehingga perogram dapat berjalan dengan lancar dan sesuai dengan tujuan yang telah ditentukan sebelumnya.

\section{A. Sosialisasi Program}

Kegiatan sosialisasi ini dilaksanakan pada bulan februari 2018 tepatnya pada tanggal 16 Februari 2017. Bertempat di balai desa Bukit Makarti kecamatan Toili Barat. Tujuan dari kegiatan ini adalah untuk memberikan pemahaman awal kepada seluruh masyarakat sasaran tentang pupuk organik cair secara umum mulai dari cara pembuatan, manfaat dan kegunaan yang bisa didapatkan dari pembuatan pupuk organik cair ini. Dalam tahapan sosialisasi pula diharapkan dapat meningkatkan minat masyarakat untuk ikut terlibat dalam kegiatan ini 
Dalam pelaksanaan sosialisasi ini tidak ditemukan kendala yang berarti oleh karena masyarakat sasaran sangat antusias dalam mengikuti kegiatan ini dan partisispasinya cukup baik. Berikut ini Dokumentasi kegiatan sosialisasi pembuatan pstisida nabati di Desa Tambale

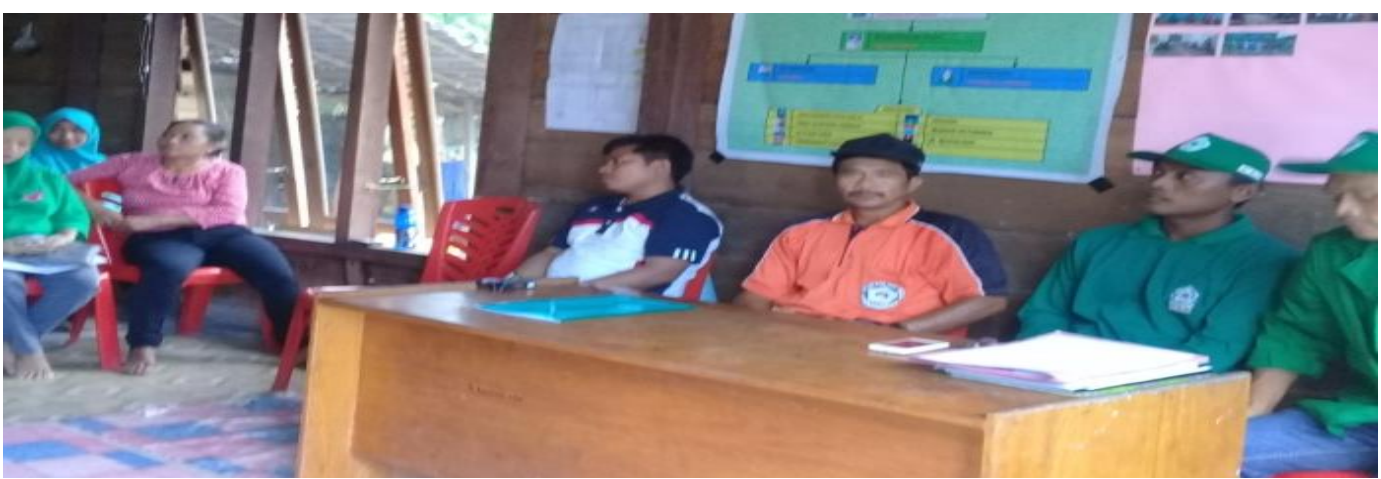

Gambar 1. Sosialiasasi Dengan masyarakat

Dilaksanakannya kegiatan sosialisasi ini diharapkan dapat memberikan pemahaman awal dan kesadaran kepada seluruh masyarakat akan pentingnya mengikuti program pembuatan pestisida nabati yang akan dilaksanakan setelah sosialisasi dilakukan.

\section{B. Pelatihan Pembuatan Pestisida Nabati}

Pendampingan pembuatan pestisida Nabati dilaksanakan selama tiga hari dengan menghadirkan seluruh masyarakat sasaran dalam hal ini petani. Pelatihan dilakukan mulai dari menyiapkan bahan yaitu menghalusakan daun srikaya yang telah tersedia sedangkan sebagaian peserta menyiapkan air dan mencampusnya dengan daun srikaya yang telah dihaluskan lalu diperas. Setelah suluruh bahan sudah siap maka langkah selanjutanya mencampurkan bahan yang telah ada menjadi satu dan diaduk merata lalu ditempatkan pada suatu wadah yakni jergen dan ember. Berikut ini gambar pelatihan pembuatan pestisida Nabati.
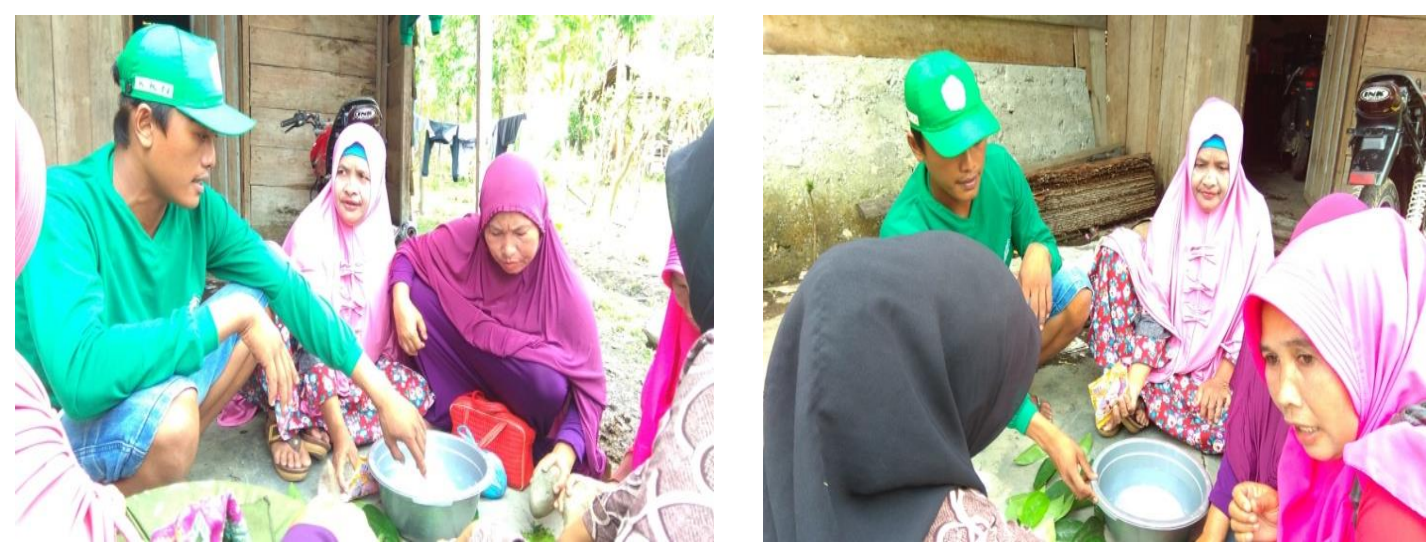

Gambar 2. Pelatihan Pembuatan Pestisida Nabati

Pelatihan yang dilakukan memberikan manfaat bagi masyarakat sasaran berupa peningakatan pengetahuan dan keterampilan masyarakat dalam membuat pestisida nabati. Selain itu potensi wilayah yang ada dapat termanfaatkan menjadi bahan yang benilai ekonomi tinggi. Bahkan jika memungkinkan kedepannya pestisida yang dibuat oleh masyarakat dapat dipasarkan ke luar wilayah desa tambale. Dengan demikian masyarakat medapatkan satu sektor untuk menambah penghasilan keluarga. 


\section{KESIMPULAN}

Berdasarkan hasil kegiatan dapat disimpulkan:

1. Tingkat pasrtisipasi masyarakat cukup baik, sehingga kegiatan yang dijalankan dapat memberikan dampak posistif bagi petani

2. Meningkatnya keterampilan masyarakat dalam membuat pestisida nabati sehingga kedepannya mereka mampu membuat sendiri pestisida untuk kebutuhan usahatani mereka.

\section{DAFTAR PUSTAKA}

Samsudin 2008. Pengendalian Hama dengan Insektisida Botani. www.pertanian. Or.id. diakses 3 maret 2018

Subiakto 2002. Pestisida Nabat, Pembuatan dan Pemanfaatan. Balai Penelitian Tanaman Horti, Lembang

Tohir A. M. 2010. Teknik Ekstrak dan Aplikasi Beberapa Pestisida Nabati Untuk Menurunkan Pelatabilitas Ulat Grayak Buletin Teknik Pertanian, 15 (1)37 -40 